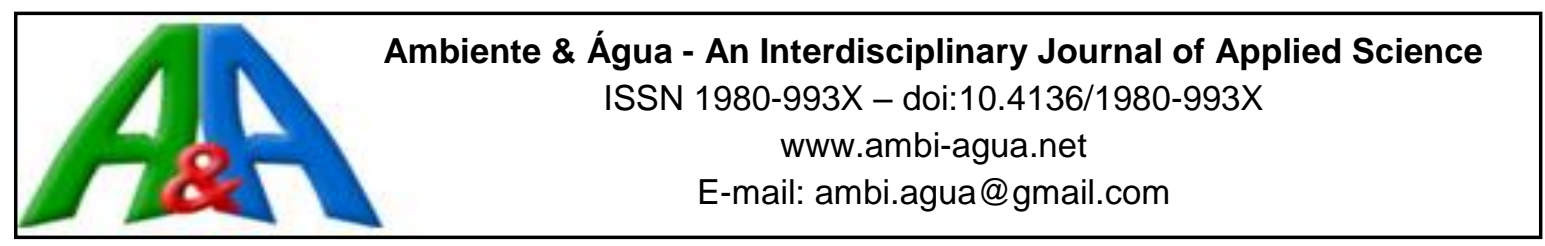

\title{
Water quality of springs in areas under different land uses in the southern highlands of Santa Catarina
}

\author{
ARTICLES doi:10.4136/ambi-agua.2201
}

Received: 23 Oct. 2017; Accepted: 17 May 2018

\author{
Saulo Tadeu Branco Ramos ${ }^{1}$; Maria Sueli Heberle Mafra ${ }^{1 *}$; \\ Tássio Dresch Rech ${ }^{1}$; Ana Emília Siegloch ${ }^{1}$; Ângela Fonseca Rech ${ }^{2}$ \\ ${ }^{1}$ Universidade do Planalto Catarinense (UNIPLAC), Lages, SC, Brasil \\ Programa de Pós-Graduação Stricto Sensu em Ambiente e Saúde (PPGAS) \\ E-mail: a2stbr@gmail.com,mshmafra@gmail.com, tassiodr@gmail.com, asiegloch@gmail.com \\ ${ }^{2}$ Empresa de Pesquisa Agropecuária e Extensão Rural de Santa Catarina (Epagri), Lages, SC, Brasil \\ E-mail: angelarech@bol.com.br \\ *Corresponding author
}

\begin{abstract}
This study sought to characterize the conditions of springs used for domestic consumption and to analyze their water quality. The springs are situated in catchment areas (drainage areas) with different soil uses in rural properties of the southern plateau of Santa Catarina, Brazil. To this end, 56 springs used to supply rural properties were selected in the counties of Lages, Otacílio Costa, São José do Cerrito, Painel, and Bocaina do Sul. The water catchment area of the springs were described in detail with regard to topography, management, forest, protection, fences, channels to contain runoff, and macroscopic aspects of water. In addition, the water was analyzed for total and fecal coliforms, $\mathrm{pH}$, dissolved oxygen, electrical conductivity, temperature, clarity, and nitrate and total phenol contents. The samplings for water analysis were performed in compliance with Standard Methods for Examination of Water and Wastewater (APHA). The above parameters were evaluated under the following soil uses in the drainage areas: native forest, native grassland, planted pine forest, and cropland. Data were analyzed by comparison of means by the Student's t test ( $\mathrm{p}<0.05$ ). More than $80 \%$ of the springs were found to be contaminated with fecal coliforms. The main risk factors for microbiological contamination in the region are extensive cattle ranching and the lack of adequate protection of the springs in most properties, with emphasis on the catchment areas of native grassland and native forest. Springs in pine forest areas have the lowest mean $\mathrm{pH}$ and the highest phenol content.
\end{abstract}

Keywords: contamination of water sources, drainage areas, spring protection.

\section{Qualidade da água de fontes em diferentes usos do solo no Planalto Sul Catarinense}

\section{RESUMO}

O objetivo deste trabalho foi caracterizar as condições das nascentes para consumo doméstico e analisar a qualidade da água destas, situadas em áreas de contribuição (microbacias), em diferentes usos do solo em propriedades rurais do planalto sul de Santa Catarina, Brasil. Para isso foram selecionadas 56 fontes utilizadas para o abastecimento 
doméstico em propriedades rurais nos municípios de: Lages, Otacílio Costa, São José do Cerrito, Painel e Bocaina do Sul. Foi realizada a caracterização detalhada da área de contribuição às fontes quanto à topografia, manejo adotado, floresta, proteção, cercas e valas de contenção de enxurradas e aspectos macroscópicos da água. Além disso, realizou-se análise da água para coliformes totais e fecais, $\mathrm{pH}$, oxigênio dissolvido, condutividade elétrica, temperatura, limpidez, nitrato e fenóis totais. As amostragens para análise seguiram as normas do Standard Methods for Examination of Water and Wastewater (APHA). Os parâmetros foram avaliados nos seguintes usos do solo nas áreas de contribuição da fonte: floresta nativa, campo nativo, reflorestamento de pinus e lavoura. Os dados foram analisados por comparação de médias pelo teste T-Student $(\mathrm{p}<0,05)$. Mais de $80 \%$ das fontes estão contaminadas por coliformes fecais. Os principais fatores de risco de contaminação microbiológica são a presença da pecuária extensiva e ausência de proteção das fontes na maioria das propriedades, com destaque para as áreas de contribuição com campo nativo e floresta nativa. Nas áreas com pinus a água das fontes tem a menor média de $\mathrm{pH}$ e maior teor de fenóis.

Palavras-chave: área de drenagem, contaminação de fontes de água, proteção de nascentes.

\section{INTRODUCTION}

The availability of water, aside from playing an essential role in production, fulfills social and environmental functions. Water is fundamental for the maintenance of life and has multiple uses, including that of human drinking water. The function of water in natural cycles ensures the ecological balance. Shortages of safe, clean drinking water are a major cause of illness and death in developing countries (Boutilier et al., 2014).

The importance of water was anchored in Resolution no. 64/292 of the United Nations General Assembly, by which clean and safe water and sanitation are acknowledged as human rights. The access to good-quality water is a precondition for food and nutritional security (SAN). The World Health Organization (WHO) and the United Nations Children's Fund (UNICEF) warn about the danger of not investing enough in clean water and sanitation, resulting in public spending to treat diseases transmitted by contaminated water in Brazil (Menezes et al., 2009).

Excessive water demand and the lack of sustainable management in the agricultural sector can compromise water resources quantitatively and qualitatively, reduce access to good-quality water for human consumption, and trigger social conflicts. Although the water demand for direct human consumption is not very representative (mean of $0.56 \%$ of the total consumption in the state of Santa Catarina) compared to the demand for livestock (accounting for 1.74\%) and for agricultural activities (97.7\%) (Conceição et al., 2013), the data from the Brazilian survey of sampled households (PNAD) showed severe inequality between urban and rural inhabitants in terms of access to water supply services. In Brazil, $66.6 \%$ of the rural households use wells or collect water directly from springs (FUNASA, 2014).

In the rural area of the highland region of Santa Catarina, residents are supplied with different water sources, e.g., from wells, springs, creeks, rivers, and artesian wells. These water sources are often used without any kind of protection or treatment, exposed to the most varied forms of contamination. The quality of water for domestic supply can be affected by pollution from different sources, such as domestic or industrial effluents, urban surface runoff, and agricultural activities (Bertoncini, 2008).

The consumption of poor-quality water can deter people from drinking enough to supply the vital necessities and may eventually compromise the health of the people. Biological contamination with total and fecal coliforms usually occurs due to the lack of physical 
protection of the springs associated with inadequate use and management of their catchment areas, mainly in the vicinity of domestic animals (Stolf and Molz, 2017).

Land use and occupation are interference factors in surface water quality, and water quality management should be based on minimizing or mitigating environmental damage. In addition, local particularities such as topography, soil type, presence/absence of forests, soil management, and the presence of livestock and other domestic animals can increase the contamination risk of springs, influencing the biological, physical and chemical water properties, mainly the levels of nitrate and fecal coliforms (Barrington et al., 2013).

In intensive agricultural production systems, the need for agrochemical applications is high, raising nitrate levels in water. The nitrate anion is weakly retained in colloidal charges and tends to remain in solution. In the soil solution, the nitrate is prone to leaching and over time, its contents may increase in the water of springs or wells. High nitrate concentrations in the water are a potential cause of damage to human health and the environment (Jadoski et al., 2010).

The phenol concentration in spring water can also be influenced by the type of land use in the drainage area that supplies the source (Turtola et al., 2002). Phenols may be toxic to human health, aquatic organisms and to microorganisms that are part of aquatic systems.

The study of the water quality of springs is based on evaluations of macroscopic (surroundings and condition of the spring) and microscopic (laboratory water analysis) aspects. In this sense, this study sought to characterize the conditions of springs used for domestic consumption and to analyze the water quality under different land uses in rural regions in the southern highlands of Santa Catarina, Brasil.

\section{MATERIAL AND METHODS}

The study was carried out in the southern highland region of Santa Catarina in the counties of Lages, Otacílio Costa, São José do Cerrito, Painel and Bocaina do Sul. Rural properties with springs were selected based on indications of agents of technical assistance and rural extension (ATER) according to the following criteria: (a) springs used for human consumption; b) surrounded by different types of land use in the drainage areas, e.g., native forest, native grassland, cropland, and planted pine forest. These four types of land use are representative of the economic activities in the studied region; the native forest and native grassland areas are used for extensive livestock raising.

The study region is located in the sub-basins of Rio Caveiras and Rio Canoas. The soils of the region are derived from the Serra Geral mountain chain, characterized by effusive rocks, and are predominantly clayey (part of the counties of Lages, São José do Cerrito and Painel). Immediately below the Serra Geral, Botucatu Sandstone is found, which is the rocky matrix of the Guarani Aquifer. This formation has a narrow outcrop, giving rise to the characteristically sandy soil. The Rio do Rastro formation range also covers a large area of the region, e.g., in Lages, Bocaina do Sul and Otacílio Costa, creating soils of varied texture.

We considered the space between the water source where it is collected and the highest point upstream that contributes to the source as drainage areas. The drainage areas of the sources were classified according to their use and predominant vegetation cover.

Samples were collected from 56 springs for laboratory analysis between March and August 2016, according to the Standard Methods for Examination of Water and Wastewater (APHA, 2012). The samplings were carried out within an interval of at least three days after rainfall above $5 \mathrm{~mm}$.

The points were characterized in detail according to the geological and topographic conditions, type of spring, form of catchment and geographical coordinates. The geological conditions, given by the predominant soil type, were evaluated macroscopically for clay or 
sandy texture. The topographic condition was defined as flat, slight or steep slope. The type of spring was classified as surface spring when it emerged at the soil surface, and as well when the water was accessed by excavation. The form of water outflow and channeling was also evaluated, differentiating between water flow by gravity or motor pump.

The preservation of the spring surroundings was evaluated with regarding the type of vegetation, presence or signs of livestock, contamination sources, type of land use and management, and macroscopic aspects of the water conditions of the springs.

The type of vegetation in the surroundings of the spring was classified as present when the spring was shaded by tree canopies, or absent when the spring was exposed.

The material at the bottom of the reservoir was classified as rock, sand, sludge, or mud. The difference between sludge and mud was distinguished by the color, since gray to black colors indicate the presence of organic material, corresponding to sludge, while the material was classified as mud when it had the appearance of clay or sand originated from the banks of the spring. The water transparency/clarity was visually assessed for the level of light crystalline appearance and absence of residue.

The presence or absence of a physical protection of the springs was evaluated, and classified as present, weak or absent. The protection was considered present when the spring was fully protected from external contamination sources, e.g., source safely enclosed below the soil surface with piping of the water from the outlet directly to the consumption location; vegetation cover of the source location with native species; and protection against animal access and other contamination sources, or encased in closed and sealed concrete tubes or boxes to prevent the entry of insects, amphibians, or larger animals. Where failures in these structures of reservoir containment were detected, the protection was considered weak, and absent where the reservoir was dug directly into the soil without protection.

Fences were considered to be present when they protectively surrounded the drainage area of the spring against animal access; weak when they allowed sporadic access of animals and did not adequately enclose them; and absent when animals had free access to the spring. Containment embankments and channeling of runoff water were only taken into consideration when they were functionally effective.

The macroscopic aspects were evaluated with regard to the presence in the spring of aquatic vegetation and foam, for water color and transparency/clarity. This evaluation of the springs was performed as described by Felippe and Magalhães Junior (2013), by a simple and practical methodology with satisfactory results, with the objective of evaluating the conservation level of springs qualitatively and visually, based on the identification of negative environmental impacts. These assessments are supplementary to the laboratory analyses and contribute to a better understanding of the forms of environmental contamination.

Water samples were collected for analysis of microbiological parameters (total coliforms and Escherichia coli), and $100 \mathrm{~mL}$ was filled in sterile $250 \mathrm{~mL}$ polypropylene flasks, in compliance with the technical norms for storage and conservation, and stored until analysis. The material used for sampling was pre-purified with water and commercial liquid detergent and the equipment used for the microbiological analyses was sterilized in an autoclave.

Microbiological analyses were performed with the Readycult ${ }^{\circledR}$ kit Coliforms 100 (Merck). The kit consists of a culture medium that determines the presence or absence of coliform bacteria and $E$. coli in the sampled water. Immediately after sampling, one dose of the kit is added to each $100 \mathrm{ml}$ water sample, followed by incubation at $36 \pm 1{ }^{\circ} \mathrm{C}$ for $24 \pm 1 \mathrm{~h}$. In the presence of coliform bacteria, the content of the sample changes from yellow to slightly greenish blue. Additionally, in the presence of E. coli, the medium emits bright blue fluorescence when subjected to ultraviolet (UV) light (wavelength $365 \mathrm{~nm}$ ). 
The following physic-chemical parameters were analyzed: $\mathrm{pH}$, temperature, electrical conductivity, and nitrate and total phenol contents. The analyses of water $\mathrm{pH}$, temperature and electrical conductivity were carried out in the field at sampling with a YSI multiparameter water quality probe. The nitrate $\left(\mathrm{NO}_{3}^{-}\right)$levels were analyzed using the Spectroquant ${ }^{\circledR}$ Nitrattest Kit (Merck) and the readings were performed in a spectrophotometer Spectroquant ${ }^{\circledR}$ (Merck).

The data were tabulated and subjected to descriptive analysis, and the means of results for the different land use types were compared by the T test using Excel® software. To compare the water quality of the sources, under the four types of land use in the catchment areas, graphic models of the radial type were organized, in which each attribute is located in one of its radii with percentage values.

\section{RESULTS AND DISCUSSION}

Of the 56 water sources sampled, 18 were found in native forest, 19 in native grassland, 11 near crop fields and 8 in planted pine forest areas. In all agricultural areas, they were surrounded by small grassland or forest patches, usually with a radius of 2-10 m springs, i.e., insufficient to offset the predominant effects of the surrounding cropland on the spring catchment.

All evaluated springs had continuous flow and $90 \%$ were surface springs. Half of the springs had a lentic character, i.e., stagnant waters with renewal; $22 \%$ were lotic and the others were intermediate. A lentic character can considerably affect water quality due to the dynamics of accumulation of polluting elements, especially in areas under intensive agricultural management.

The slope was gentle at $54 \%$ of the locations; the water supply of $68 \%$ of the residences was actuated by gravity (Table 1) and that of the others by motor pumps.

The predominant soil near the springs was clayey in $93 \%$ of the drainage areas (Table 1). Only at four sampling sites (two in São José do Cerrito in areas of Botucatu sandstone outcrop and two in Bocaina do Sul) sandy soil was predominant.

Table 1. General properties of the environment of domestic water sources in rural properties of the southern highlands of Santa Catarina.

\begin{tabular}{|c|c|c|c|c|c|c|c|c|c|c|}
\hline $\begin{array}{l}\text { Spring } \\
\text { type }\end{array}$ & \multicolumn{3}{|c|}{ Topography } & \multicolumn{2}{|c|}{$\begin{array}{l}\text { Predominant } \\
\text { soil type }\end{array}$} & \multicolumn{4}{|c|}{$\begin{array}{c}\text { Bottom } \\
\text { of the reservoir }\end{array}$} & $\begin{array}{c}\text { Water } \\
\text { conduction }\end{array}$ \\
\hline \multirow[t]{2}{*}{ Superficial } & Steep & Gentle & Plane & Clayey & Sandy & Rock & $\mathrm{Mud}^{1}$ & Sand & Sludge $^{2}$ & \multirow[t]{2}{*}{ Gravity } \\
\hline & & & & & $\%$ & & & & & \\
\hline 90 & 23 & 54 & 23 & 93 & 7 & 12 & 43 & 3 & 42 & 68 \\
\hline
\end{tabular}

1 - fine material (clay/silt), with no visible presence of organic material; 2 - fine material with visible presence of organic material.

Regarding management of the areas surrounding springs, $84 \%$ were not enclosed with fences. In the springs located in pine forests and native grassland, respectively, 100 and 95\% had no protective fences (Figure 1). Cattle or animal traces, such as trampling and feces, were observed at $64 \%$ of the springs. This occurrence was even more common at springs in native forest and native grassland areas, where bovines and other animals had free access to almost $100 \%$ of the springs.

Cattle trampling near springs forms mud and contributes to the silting of the reservoirs during flooding periods. This fact is aggravated by the formation of animal tracks leading to the springs that function as drainage channels, by which dung and contaminants are swept into the springs, while the soil near the springs is compacted. On the other hand, the presence of

\section{IPABH}

Rev. Ambient. Água vol. 13 n. 4, e2201 - Taubaté 2018 
animals around water springs affects the water quality and poses serious risks to human health. Contamination by animals may, for example, become a vehicle for contamination of pathogenic organisms, such as tuberculosis, brucellosis, foot-and-mouth disease, leptospirosis and parasites that can contaminate humans (Daker, 1976).
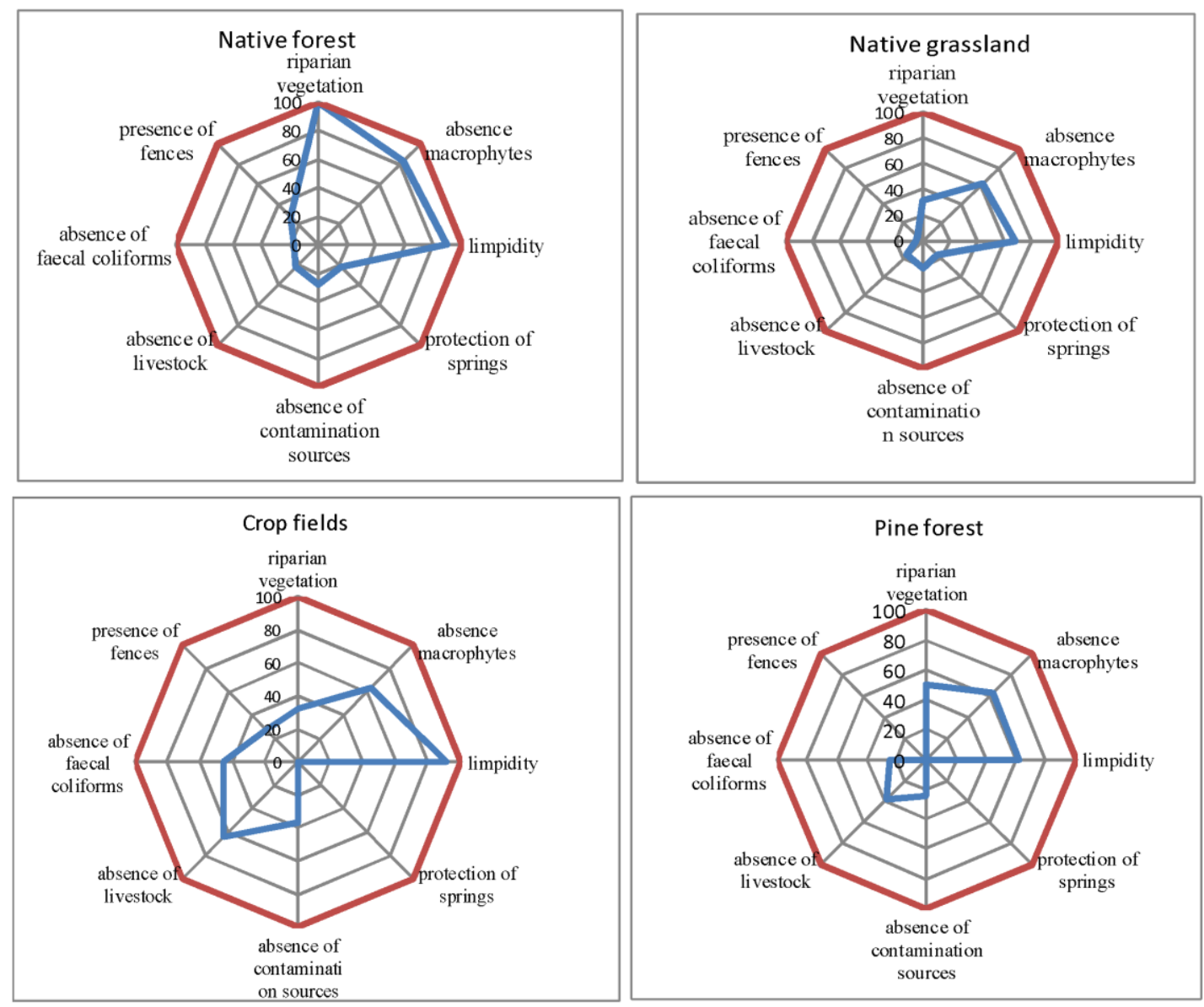

Figure 1. Radial plot of environmental and biological parameters in relation to land uses. The ideal situation is defined by the line circumscribing the entire plot area.

The riparian vegetation of springs in native forest areas had the highest level of conservation in an evaluation according to the minimum criteria established by Federal Law $\mathrm{n}^{\circ}$. 12.651/2012, known as the New Forest Code (Brasil, 2012). However, in most drainage areas, the presence of cattle and a high degree of degradation of the native forest were observed, with the exception of some difficult-access locations. The riparian area around most springs located in native grassland and cropland areas, if present at all, consisted of small tree groups restricted to the spring margin or scattered in the field, insufficient to represent an effective protection area.

Only $12 \%$ of the springs used for human consumption had sufficient protection to ensure potability. At $48 \%$ of the springs there was no protection or management of any kind. In these sites, the water was collected in a hollow, dug into the soil, forming a water puddle or pond, which is silted at flooding and contains algae, macrophytes, and organic material. Forty percent of the springs were encased in concrete boxes or tubes and covered with wood, asbestos cement or steel sheets, but were not safely protected against contamination.

The most common deficiencies observed in the spring sources protection were rotten covers, part of the reservoir outside the fenced area, use as watering place for animals, very 
restricted enclosure, absence of embankments for water containment and diversion, contamination by runoff, and lack of maintenance.

The predominance of clayey soils on the banks contributed to the presence of mud at the base of $44 \%$ of the studied springs (Table 1). In the presence of animals, it was common to find dark sludge at the bottom of the reservoir, indicating organic matter from animal feces, which can promote the growth of phytoplankton and aquatic macrophytes. The presence of spongy or filamentous (mossy) materials was observed in the water of $28 \%$ of the springs, varying from brown to green, with foam. Water transparency and color can be indicators of several problems related to water quality. The lack of transparency/clarity (turbidity) and presence of color, as observed in $23 \%$ of the sampled springs, can be attributed mainly to suspended solid particles that interfere with light transmission in the medium. Turbidity can be caused by plankton, algae, organic debris, and other substances, such as zinc, iron precipitates, manganese compounds and sand resulting from natural erosion or domestic pollutants. Some alga species produce toxins in water resources that are harmful to animals and humans, for example the cyanobacteria Microcystis, which produces hepatotoxic microcystin (Azizullah et al., 2011).

Among the macroscopic parameters in different land uses, the native forest areas stood out with springs with less macrophyte (aquatic vegetation) growth, and more limpid and colorless water. These characteristics are mainly due to the lower light incidence within the forest and the higher water infiltration capacity in the soil. The worst situation was identified for springs located in native grassland and pine forest areas, in which the values of all analyzed parameters were unsatisfactory (Figure 1).

In the coliform analysis, total coliforms were detected in $95 \%$ of the spring sources, and fecal (thermotolerant) coliforms in $82 \%$. The presence of fecal coliforms was detected in $83 \%$ of the springs located in native forests, in $95 \%$ of those in native grassland, $75 \%$ of those in pine forests, and in 55\% of those in cropland (Figure 1). It is worth mentioning that the incidence of fecal coliforms in springs in cropland areas was low, coinciding with a lower cattle stocking rate. For rural areas with untreated water, these results are not new in the literature (Stolf and Molz, 2017). The greater amount of contaminated springs in native forest and native grassland was due to the higher concentration of animals at these locations. The presence of fecal coliforms is an indicator of contaminants from warm-blooded animals and represents risks of transmission of several infectious diseases (Brasil, 2011; CONAMA, 2005).

The water $\mathrm{pH}$ of the springs ranged from 5.46 to 9.84, with an overall mean of 6.28 (Table 2). Regulation $\mathrm{N}^{\circ}$. 2,914 of the Ministry of Health recommends a $\mathrm{pH}$ in the range of $6.5-8.8$ for drinking water, tolerating values between 6.0 and 9.0. Overall, $32 \%$ of the springs had a pH of less than 6.0. The mean $\mathrm{pH}$ of springs located in pine forests was 5.9, and 75\% were beyond the acceptable range of the threshold determined by the regulation. Significant differences were observed between the $\mathrm{pH}$ of springs in pine forests compared to those in native grassland and native forests (Table 2). In a study of springs in the state of Minas Gerais, Barcellos et al. (2006) observed that $47 \%$ of the springs did not fit into the $\mathrm{pH}$ range of regulation $\mathrm{n}^{\mathrm{o}}$. 2,914 of the Ministry of Health and resolution $\mathrm{n}^{\circ} .357$ of CONAMA. The water $\mathrm{pH}$ of the springs may be influenced by the soil $\mathrm{pH}$, which is in a range of 4.0 to 5.5 , under the natural conditions of the southern highlands of Santa Catarina.

The overall mean dissolved oxygen (DO) of 5.76 (Table 2) was below the value of the CONAMA resolution no. 357 of 2005 (DO $>6.0 \mathrm{mg} \mathrm{L}^{-1}$ ), by which only $36 \%$ of the springs fit in Water Class 1 . There were no significant differences at $5 \%$ between the means of different land uses in the drainage areas (Table 2).

The mean electrical water conductivity (EC) was $40 \mu \mathrm{S} \mathrm{cm}^{-1}$ in the analyzed springs. This value falls within the range established for natural water bodies which, according to the FUNASA control manual of water quality ETAS, should have EC levels between 10 and $100 \mu \mathrm{S} / \mathrm{cm}$ (FUNASA, 2014).

\section{IPABH}

Rev. Ambient. Água vol. 13 n. 4, e2201 - Taubaté 2018 
Table 2. Physical-chemical water properties of springs, means and standard deviation (SD) according to land use in the drainage areas of springs.

\begin{tabular}{lcccccc}
\hline & $\mathrm{pH}$ & $\begin{array}{c}\mathrm{DO} \\
\left(\mathrm{mg} \cdot \mathrm{L}^{-1}\right)^{\mathrm{ns}}\end{array}$ & $\begin{array}{c}\mathrm{EC} \\
(\mu \mathrm{S} / \mathrm{cm})^{\mathrm{ns}}\end{array}$ & $\begin{array}{c}\mathrm{T} \\
{ }^{\circ} \mathrm{C}^{\mathrm{ns}}\end{array}$ & $\begin{array}{c}\text { Nitrate } \\
\mathrm{mg} \mathrm{L}^{-1} \text { ns }\end{array}$ & $\begin{array}{c}\text { Phenols } \\
\left(\mathrm{mg} . \mathrm{L}^{-1}\right)\end{array}$ \\
\hline Native forest & $6.34 \pm 0.46 * 1$ & $5.76 \pm 1.75$ & $42 \pm 0.014$ & $15.9 \pm 2.7$ & $1.03 \pm 0.68$ & $0.021 \pm 0.01 * 3$ \\
Native grassland & $6.48 \pm 1.14 * 2$ & $5.64 \pm 1.99$ & $37 \pm 0.017$ & $15.5 \pm 2.2$ & $0.84 \pm 0.97$ & $0.027 \pm 0.01$ \\
Cropland & $6.09 \pm 0.41$ & $6.09 \pm 2.23$ & $45 \pm 0.018$ & $14.4 \pm 4.5$ & $0.54 \pm 0.95$ & $0.021 \pm 0.01 * 4$ \\
Pine forest & $5.91 \pm 0.36 * 1.2$ & $5.64 \pm 1.4$ & $38 \pm 0.029$ & $15.1 \pm 2.2$ & $1.11 \pm 1.52$ & $0.032 \pm 0.01 * 3.4$ \\
Overall mean & $6.28 \pm 0.76$ & $5.76 \pm 1.85$ & $40 \pm 0.018$ & $15.4 \pm 2.8$ & $0.88 \pm 0.98$ & $0.025 \pm 0.01$ \\
\hline
\end{tabular}

${ }^{\text {ns }}$ no significant contrast. $* 1$ Differ from each other by the $\mathrm{t}$ test $(\mathrm{p}<0.01)$ and; $* 2, * 3$ and $* 4$ Differ from each other by the $t$ test $(p=0.05)$.

The water temperature of the springs ranged from 6 to $19^{\circ} \mathrm{C}$, with a mean of $15.5^{\circ} \mathrm{C} \pm 2.8$. The variation in the atmospheric temperature observed in the days of sampling ranged from 6 to $22^{\circ} \mathrm{C}$. It is known that the water temperature of the springs can vary according to the climate variations throughout the year (Marmontel and Rodrigues, 2015). Although the presence of riparian forest may mitigate water temperature fluctuations caused by the variation in atmospheric temperature, the mean water temperatures of the springs under the studied land uses did not differ from each other at $5 \%$ probability.

The nitrate $\left(\mathrm{NO}_{3}{ }^{-}\right)$contents in the water were below the maximum permitted value (MPV) of $10 \mathrm{mg} \mathrm{L}^{-1}$ established by CONAMA resolution $\mathrm{n}^{\circ} .357$ of 2005 and regulation $\mathrm{n}^{\circ} .2,914$ of Ministry of Health/2011 (Brasil, 2011; CONAMA, 2005). The general content was $0.88 \mathrm{mg} \mathrm{L}^{-1} \pm 0.98$, with a minimum of $<0.2$ and maximum values of $4.2 \mathrm{mg} \mathrm{L}^{-1}$. Under the different land uses in the spring catchment areas, the means did not differ from each other, ranging from $0.54 \pm 0.95$ to $1.11 \pm 1.52 \mathrm{mg} \mathrm{L}^{-1} \mathrm{NO}^{3-}$.

Despite the presence of animals around most of the analyzed springs, the observed $\mathrm{NO}_{3}$ levels indicate a reasonable presence of native forest and non-intensive management of agricultural and livestock areas, in particular upstream of the spring catchment areas. The presence of nitrogen in the water is usually a consequence of intensive fertilization. However, since the main crop was soybean, little or no $\mathrm{N}$ fertilizer was applied, and in addition, the data were collected in a fallow period of the soil.

The phenol content in the water exceeded the MPV of the CONAMA resolution $n^{\circ} .357$ of 2005, determining a limit of $0.003 \mathrm{mg} \mathrm{L}^{-1}$ (CONAMA, 2005). The overall mean was $0.025 \mathrm{mg} \mathrm{L}^{-1}$, with a minimum of 0.008 and a maximum of $0.048 \mathrm{mg} \mathrm{L}^{-1}$ (Table 2).

Under the different land uses in the spring catchment area, the mean phenol contents were $0.027,0.021,0.021$, and $0.032 \mathrm{mg} \mathrm{L}^{-1}$, respectively, in the native grassland, native forest, cropland, and pine forest areas. The mean phenol contents in the springs in pine forests were significantly higher than the means of the native forest and cropland areas and did not differ from native grassland ( $\mathrm{p}<0.05$ ) (Table 2). Although the phenol concentration in water may have different origins, in rural environments where industrial pollution is less likely, they may be a result of the degradation of organic residues added to the soil, or released directly from lignin and oxidative phenols that contribute to the formation of defensive barriers. In addition, in these environments, this fact may be related to the volume of pine needles that remain on the soil surface, and during decomposition release phenols that are carried into the water (Turtola et al., 2002).

It is worth emphasizing that the MPVs of the legislation are defined for water for urban consumption, in which the presence of phenols of industrial origin is more likely. However, in natural environments, less susceptible to the contamination of synthetic phenolic products, the main contamination sources may be the decomposition of organic residues and the type of vegetation cover in the catchment areas (Charrière et al., 1991). 


\section{CONCLUSIONS}

More than $80 \%$ of the springs in southern highlands of Santa Catarina are contaminated with fecal coliforms and approximately half of these springs have a low content of dissolved oxygen, which may result from the high content of microorganisms.

The most contaminated spring sources with fecal coliforms were those where the catchment areas were occupied by native grassland and native forests, while in cropland areas where few cattle were present, contamination was lower.

The main risk factors for contamination of the springs in the region are the lack of protection of the springs and cattle ranching on most farms. These are more severe for the springs in the catchment areas used with native pasture, followed by the areas of native forest and planted pine.

The type of land use in the catchment areas also influences the $\mathrm{pH}$ and phenolic contents. Approximately half of the analyzed water sources present $\mathrm{pH}$ below the potability standards, while the phenol content exceeds the MPV established by current legislation. This fact is more pronounced for the water sources in pine forests.

The low water quality observed on the farms reinforces the importance of this type of study for the evaluation of health risks of the rural populations and of the environmental impact of human activities. Our results highlight the need for sustainable development plans aimed at the quality of life of rural populations and the need to raise public awareness and to inform the population regarding the need to preserve the quality of water resources on rural properties.

\section{ACKNOWLEDGMENTS}

The authors are indebted to the project Evaluation of heavy metals in tributaries of the Canoas River in an urban aquifer recharge area (Fapesc2015TR1069), in the framework of the Guarani/Serra Geral Network Project and gratefully acknowledge the financial support of ANA/CNPq/CAIXA/FAPESC.

\section{REFERENCES}

\section{AMERICAN PUBLIC HEALTH ASSOCIATION. Standard methods for the examination of water and wastewater. Washington, D.C., 2012.}

AZIZULLAH, A.; KHATTAK, M. N. K.; RICHTER, P.; HÄDER, D. P. Water pollution in Pakistan and its impact on public health - A review. Environment International, v. 37, n. 2, p. 479-497, 2011. https://doi.org/10.1016/j.envint.2010.10.007

BARRINGTON, D. J.; GHADOUANI, A.; SINANG, S. C.; IVEY, G. N. Development of a new risk-based framework to guide investment in water quality monitoring. Environmental Monitoring and Assessment, v. 186, n. 4, p. 2455-2464, 2013. https://doi.org/10.1007/s10661-013-3552-1

BARCELLOS, C. M.; ROCHA, M. da; RODRIGUES, L. dos S.; COSTA, C.; OLIVEIRA, P. R. de; SILVA, I. J. da et al. Avaliação da qualidade da água e percepção higiênicosanitária na área rural de Lavras, Minas Gerais, Brasil, 1999-2000. Cadernos de Saúde Pública, v. 22, n. 9, p.1967-1978, 2006.

BERTONCINI, E. I. Tratamento de efluentes e reúso da água no meio agrícola. Tecnologia \& Inovação Agropecuária, v. 1, n. 1, p. 152-169, 2008.

BOUTILIER, M. S. H.; LEE, J.; CHAMBERS, V.; VENKATESH, V.; KARNIK, R. Water Filtration Using Plant Xylem. Plos One, v. 9, n. 2, p. 1-8, 2014. https://doi.org/10.1371/journal.pone.0089934 
BRASIL. Lei 12.651, de 25 de Maio de 2012. Dispõe sobre a proteção da vegetação nativa; altera as Leis nos 6.938, de 31 de agosto de 1981, 9.393, de 19 de dezembro de 1996, e 11.428, de 22 de dezembro de 2006; revoga as Leis nos 4.771, de 15 de setembro de 1965, e 7.754, de 14 de abril de 1989, e a Medida Provisória no 2.166-67, de 24 de agosto de 2001; e dá outras providências. Diário Oficial [da] União, 28 maio 2012.

BRASIL. Ministério da Saúde. Portaria n ${ }^{\circ}$ 2.914, de 12 de dezembro de 2011. Dispõe sobre os procedimentos de controle e de vigilância da qualidade da água para consumo humano e seu padrão de potabilidade. Diário Oficial [da] União, Seção 1, 26 mar. 2011. p. 266.

CHARRIÈRE, B.; GADEL, F.; SERVE, L. Nature and distribution of phenolic compounds in water and sediments from Mediterranean deltaic and lagunal environments. Hydrobiologia, v. 222, p. 89-100, 1991. https://doi.org/10.1007/BF00006096

CONSELHO NACIONAL DO MEIO AMBIENTE - CONAMA (Brasil). Resolução n ${ }^{0} 357$ de 17 de março de 2005. Dispõe sobre a classificação dos corpos de água e diretrizes ambientais para o seu enquadramento, bem como estabelece as condições e padrões de lançamento de efluentes, e dá outras providências. Diário Oficial [da] União, 18 mar. 2005.

CONCEIÇÃO, G.; VIANNA, L. F. N.; BACIC, I. L. et al. Análise espacial do balanço hídrico no meio rural de Santa Catarina. Revista Brasileira de Recursos Hídricos, v. 18, n. 4, p. 89-100. 2013.

DAKER, A. A água na agricultura; captação, elevação e melhoramento da água. 5. ed. São Paulo: Livraria Freitas Bastos, 1976. 379 p.

FELIPPE, M. F.; MAGALHÃES JUNIOR, A. P. Conflitos conceituais sobre nascentes de cursos d'água e propostas de especialistas. Geografias, v. 9, n. 1, p. 70-81. 2013.

FUNDAÇÃO NACIONAL DE SAÚDE - FUNASA (Brasil). Manual de controle da qualidade da água para técnicos que trabalham em ETAS. Brasília, 2014. 112 p.

JADOSKI, S. O.; SAITO, L. R.; PRADO, C. et al. Characteristics of the nitrate leaching in intensive farming areas. Applied Research \& Agrotechnology, v. 3, n. 1, p. 193-200, 2010. https://doi.org/10.5777/paet.v3i1.1008

MARMONTEL, C.; RODRIGUES, V. Parâmetros indicativos para qualidade da água em nascentes com diferentes coberturas de terra e conservação da vegetação ciliar. Floresta e Ambiente, v. 22, n. 2, p. 171-181, 2015.

MENEZES, J. M.; PRADO, R. B.; SILVA JÚNIOR, G. C. da. et al. Qualidade da água e sua relação espacial com as fontes de contaminação antrópicas e naturais: bacia hidrográfica do rio São Domingos - RJ. Engenharia Agrícola, v. 29, n. 4, p. 687-698, 2009. https://doi.org/10.1590/S0100-69162009000400019

STOLF, D. F.; MOLZ, S. Avaliação microbiológica da água utilizada para consumo humano em uma propriedade rural de Taió - SC. Saúde e Meio Ambiente, v. 6, n. 1, p. 96-106, 2017. http://dx.doi.org/10.24302/sma.v6i1.1104

TURTOLA, S.; MANNINEN, A. M.; HOLOPAINEN, J. K.; LEVULA, T. et al. Secondary metabolite concentrations and terpene emissions of scots pine xylem after long-term forest fertilizations. Journal of Environmental Quality, v. 31, v. 5, p.1694-1701, 2002. http://dx.doi.org/10.2134/jeq2002.1694 